\title{
Aesthetics of Excess: The Singing and Dancing of Pey in the Folktales from Karisial Kädu
}

\author{
Swathi Sudhakaran ${ }^{1} \&$ Milind Brahme ${ }^{2}$ \\ ${ }^{1}$ Ph.D. candidate, Humanities and Social Sciences Department, IIT Madras. ORCID id: \\ http://orcid.org/oooo-0002-9599-o881. Email id: ammusswathi@gmail.com \\ ${ }^{2}$ Associate Professor, Humanities and Social Sciences department, IIT Madras \\ ORCHID id: http://orcid.org/oooo-ooo1-5427-4611. Email id: brahme@iitm.ac.in
}

\begin{abstract}
The article explores the singing and dancing of pey, a dual spirit (benevolent and malevolent) found in the folktales from Karisial Kädu (the area around Tuticorin district in southern Tamil Nadu, India) as embodying aesthetics of excess. The tales have been collected by Ki. Rajanarayanan in Națupura Katai Kalañiyam (repository of folktales). Although a dual spirit, pey belongs to the sacred in Karisial Kädu. The divine world of Karisial Kädu populated by folk deities conceptualizes sacred differently from the scriptural religion and its pantheon of pan-Indian deities. This divide in the divine world becomes apparent in an aesthetic that characterizes the singing and dancing of the pey in these stories. As a response to and a manifestation of an excess it disturbs composure and does not fit into the controlled and transcendental aesthetics of Nätyaśästra. The paper studies this deviant aesthetics associated with the singing and dancing of pey and its function in Karisial Kädu through the lens of the Nietzchean category of the Dionysian.
\end{abstract}

Keywords: aesthetics, aesthetics of excess, folk deities, dionysian, Karisial Kādu

\section{Introduction}

Karisial Kādu (black cotton soil) covers the taluks Kovilpatti, Ottapidaram, Ettayapuram, Vilathikulam, Sattur, and Sivakasi, in Tuticorin and Virudhunagar district of southern Tamil Nadu (Venkatachalapathy, 2018). Unlike the rich wet south that became a domain of Brahmin enclave and spectacular stone-built temples, most of the territory outside the favored deltas and valleys, to which Karisial Kādu belongs, remained unsettled inhabited largely by "martial predators, forest and hill dwelling hunter-gathers and predatory cattle-keeping plainsmen such as the Kallars, Maravas, and Akamutaiyars" (Bayly, 1989/1992, p. 22). Shaped by a different lived reality, Karisial literature is distinctive from the literature born out of the Tamaraparani and Kaveri basins. With scarce reference in ancient and medieval historical narratives, a distinct idea called Karisial comes of age only in the twentieth century. It is with the writings of Ki. Rajanarayanan that Karisial literature makes a mark in the literary scene. With his entry, the dialect and demotic make their mark in the literary world (Venkatachalapathy, 2018).

(c) AesthetixMS 2021. This Open Access article is published under a Creative Commons Attribution Non-Commercial 4.0 International License (http://creativecommons.org/licenses/by-nc/4.o/), which permits non-commercial re-use, distribution, and reproduction in any medium, provided the original work is properly cited. For citation use the DOI. For commercial re-use, please contact editor@rupkatha.com. 
The stories collected by Ki. Rajanarayanan in Națupura Katai Kalañiyam (repository of folktales) have no known author or date of origin. These stories told and re-told by the people of the Karisial Kādu entail an imagination and morality that would make a modern reader dismiss them as offensive. Ki Rajanarayanan (2006/2008), however, says that these tales reveal the tension caused by the repression of sexuality in a highly moralized society. This difference in the conceptualization of morality in these folktales, the paper argues, is directly linked to the divine worlds of the deities that populate the Karisial Kādu. It is reflected in the aesthetics as much as in the morality associated with them and is best encapsulated in the singing and dancing of pey in these stories.

Pey, a dual spirit both malevolent and benevolent, is a mundane presence in the folktales collected by Ki. Rajanarayanan from Karisial Kādu. Although a dual spirit, pey belongs to the sacred of society. Fuller (2004) says pey is a malevolent spirit and can be appeased by deifying it, by giving it a cult; the village deities Madan and Karuppan, for example, are deified peys. Deified pey, along with the dark forms of the great gods, the single, independent goddess, and the little or village deities, constitute the pantheon of folk deities. Linked to their locality, with limited power over specific things, they are concerned with the land, the earth below, and the everyday. The transcendental pan-Indian deities, Vishnu, Siva, and the wifely form of the goddess, on the other hand, concern themselves with the cosmos and the cosmic.

It is to be noted that the space that pey occupies is a $k \bar{a} d u$ (wilderness). Masilamani-Meyer (2004) says that unlike the ordered, domesticated space, the kādu signifying the wild is the place of the outsider. Conceptualizing wilderness and ordered space as physical and mental spaces, she says folk traditions belong to the wilderness and codified Hinduism to the ordered space. The difference in the spaces characterizes the nature of gods in both traditions. Ghost and malevolent gods that wander in the $k \bar{a} d u$ are fierce as opposed to the soft deities that are allowed inside the temple (Mines, 1997).

The fierce nature of these deities arises from the unrestrained sexual energy in them and is directly linked to the fertility of the land (Fuller, 2004). Unlike the scriptural deities, these deities embody excess and not restraint. Varadpande (1981) draws a connection between the arts, theatre in particular, and a libidinal excess associated with local deities. He says in pre-Vedic Indian societies, worship and festivals held in honor of deities such as the fertility goddess are characterized by dancing and singing. Such pre-Vedic local traditions associated with phallic deities have influenced the evolution of theatre.

The paper investigates this relationship between folk religion and the performing arts in the Indian context. That there is religion in the performing arts of India is apparent says Schwartz (2008). She further argues that religion in India is performing art and not a mere theme in it. Religion, in this context, is an experiential phenomenon and is not used in its institutional, denominational, textual, or political sense. Nätyaśástra, the most important treatise on performing arts in India is elevated to the status of Veda. Unlike Poetics - an ancient text that occupies a similar position in Europe - which is secular, Nätyaśástra is a sacred text authorized by the gods (Schechner, 2001).

The desired function of art in Nätyaśāstra is brought about by transcendence. The experience of the rasa (the emotion produced by the configuration of vibhāva (stimulus), anubhāva (involuntary reaction), and vyabhicāri bhāva (voluntary reaction) savored by the audience) is transcendental in the sense that it offers the spectator a fleeting taste of supreme bliss or brahmānanda (Rao, 1967). Abhinavagupta draws an analogy between the taste of rasa (rasāsvāda) and the relishing of the ultimate reality (brahmāsvāda). His preference for śánta rasa as the pre- 
eminent rasa is due to its proximity to the religious experience of achieving mokssa (Gerow \& Aklujkar, 1972). Transcendence central to Nātyaśāstra is, hence, intertwined with religion. Religion here is the Vedic, scriptural Hinduism with its pantheon of pan-Indian deities. Schwartz (2008), points out that the deities associated with the eight rasas are Vedic.

Although Nātyaśāstra refers to a host of bhūtaganas - malevolent spirits such as pey - among other pan-Indian deities, the aesthetics it deems desirable is a controlled transcendental aesthetics linked to the scriptural deities. Nätyaśästra says that long ago "people of this world of pain and pleasure, goaded by greed and avarice and jealousy and anger, took to uncivilized (lit:grāmya=vulgar) ways of life" (Muni \& Rangacharya, 1984/2018, p. 1). As a solution to the problem, Bharatha composes Nātyaśāstra, it says, "[H]ere is the Nātyaveda. Let the sura-s (gods) practice it. It requires persons who are smart, intelligent, observant and self-controlled" (Muni \& Rangacharya, 1984/2018, p. 1). Art, according to Nätyaśāstra, checks vulgarity in the society thereby civilizing it. The goal of the civilizing mission is to contain the undesired excess.

The paper studies the aesthetics associated with folk religion by exploring the singing and dancing of pey in the folktales collected by Ki Rajanarayanan from Karisial Kädu. The aesthetics and function associated with the singing and dancing of pey vary from the controlled transcendental aesthetics of Nātyaśāstra. The study is an attempt to examine this departure from the dominant idea of aesthetics associated with Nätyaśāstra through a close analysis of the singing and dancing of pey in the story numbers 32, 37 and 55 from the section Eyarkkai, Dāivam, Pey Mudhaliyane Patriya Kadhaigal (Stories about Nature, God, and Ghosts) from Ki. Rajanarayan's collection, Natupura Katai Kalañiyam (repository of folktales).

\section{The Singing and Dancing of Pey}

In story number 32, the pey lives in the foothill of Arasanallur village. It is malevolent in disposition and craves to drink the blood of the brothers who come to graze the sheep at the foot of the village hill. The pey, however, is tricked and wounded by the brothers. One of the brothers, Anjādhān, replaces the idol of Aiyyannar (a male guardian deity) and takes its place to trick the pey. On seeing the idol (one of the brothers here) swallow the bananas it offers, a dumfounded pey begins to sing,

“ayyo enna ithe?(kine kine)

Sami valäipaḷam thinnuthe (kine kine)” (Rajanarayanan, 2016, p. 90).

"What is this? (ga-ning, ga-ning)

The idol is swallowing bananas! (ga-ning, ga-ning)" (Rajanarayanan, 2006/2008, p. 90).

The pey then breaks into a frenzied dance, says the story. The singing, however, appears as screams to Anjādhān, and unable to bear it, he pokes the pey hard with a trident. The terrified pey begins to wail,

“appove sonnene!(kine kine)

Enne ne viṭide (kine kiṇe” (Rajanarayanan, 2016, p. 90).

"I told you then, (ga-ning, ga-ning)

Please let me go! (ga-ning, ga-ning)" (Rajanarayanan, 2006/2008, p. 90).

The terror-stricken pey then begins to run; the brothers run after it for some time and chase it away.

Story number 55 features a specific category of pey called the kaniam pey. The story says that there are different kinds of pey with varying obsessions and the kaniam pey is characterized by 
an interest in beautiful women. The kaniam pey describes through the exorcist, its quest for the woman as it is aroused by the scent of Puvāyi, the new bride who had decked her hair with jasmine and smeared her body with turmeric and sandal paste. Being haunted by the pey causes Puvāyi much suffering. Through the exorcist the pey sings the following song to the people who are gathered there to look for a solution to Puvāyi's distress.

“enna eṇāi thalāimooluvi

Ekantha pote veche

Vanakavi padi

Varukiravelayile...

... yen

Odambe thakikkithappā

Ullellam nokuthappā

Pithe pidichavana" (Rajanarayanan, 2016, pp. 135-136).

"I, with oiled hair

Smelling Divine

Singing an amorous song

Was on my way.

...How aroused I was

When I approached her!

See how my body still throbs!

My fevered heart

Was driving me to frenzy" (Rajanarayanan, 2006/2008, p. 95).

The story refers to two kinds of singing. One, when the kaniam pey is aroused by the young bride Puvāyi, it is described as amorous by the kaniam pey. The story doesn't give many details about the nature of the amorous song of the pey. It, however, talks about a frenzy it is about to enter into. It can hence be inferred that the dance of the aroused pey is frenzied. The second song quoted above is sung by the exorcist possessed by the kaniam pey. The story says the husband was disgusted with the pey's dirty song. Dirty here refers to the way the pey describes and humiliates Puvāyi, rather than it not being mellifluous as in the previous story.

Story number 37 features another kind of pey called the kanni pey. If the kaniam pey is interested in beautiful women, it's jewelry that the kanni pey desires. When Gomathi realizes that she has lost her necklace to somebody who had taken the form of Parvathi and tricked her into giving away her diamond necklace, Parvathi, her friend, concludes that it must be a jewel-crazy kani-pey who must have done it. In their quest to find the necklace, they find the peys singing and dancing with the diamond necklace in an orchard at high noon. The story gives the most elaborate description of the dance of the kanni peys. The peys singing "akka thantha necklace ennakke kode" (Rajanarayanan, 2016, p. 97), translated as "give me the necklace that akka gave you" (Rajanarayanan, 2006/2008, p.97), is described as an eerie melody. They see seven kanni peys 
dancing and wearing the necklace in turns admiring themselves. They are described in the story as naked young girls with disheveled hair.

The singing here, unlike in story number 32, is not unbearable. Gomathi joins the peys in their dance to get her necklace back. She is initially reluctant to strip naked and dance. However, she has to overcome this restraint and join the dance of the peys to get her necklace back. Thus we see human participation in the dance of the peys.

\section{Discussion}

Ki Rajanarayanan (2006 / 2008) says that there are many stories in Tamil Nadu about pey. He says these stories were told by adults to children to teach them not to be afraid of ghosts. The sound effect such as kinekine in the stories indicates that it is meant to appeal to a younger audience. These stories told to children by adults can be classified as ajjikate or granny's tale. Narrated in the private space without offering apologies to the heavens or formal greeting to public audience, these folktales belong to the akam genre (Ramanujan, 1986).

The three stories follow the pattern: violation - overpowering. The first part of the stories is about a violation of some kind by the pey, in story number 32 - its attempt to drink the brothers' blood, in story number 55 - the attack on and the subsequent humiliation of Puvāyi, and in story number 37 - the theft of Parvathi's diamond necklace. Pey appears to be more powerful than humans and is feared in the first part. This, however, is followed by the overpowering of pey in the second part. Pey is overpowered by tricking it in all three stories. Human intelligence hence triumphs over the powers of pey in the stories.

Although a dual spirit, mostly malevolent and benevolent, pey is a mundane presence in Karisial Kādu in these stories. It is a part of the everyday and occasional encounter with it is considered normal. This strange familiarity people have with the pey, despite it being a supernatural being, is because it shares a lot of human-like qualities (Kakar, 1982)- like its desire for jewelry or women as in the case of kanni pey and the kaniam pey respectively. The pey is also vulnerable to human attack as it can be wounded, scared off and it even worships deities such as Aiyyannar as can be seen in story number 32. It is as tangible as it is mysterious and co-exists with the humans in the Karisial cosmos.

While being a mundane presence in the Karisial Kädu, pey, the dark spirit, moves beyond the accepted in the society. It is amoral, transcends the boundaries of right and wrong, and breaks taboos of the Karisial cosmos. It is the spillage that fails to be contained in the consciousness of the Karisial Kādu. Kakar (1982) calls such spirits,

something that is powerful and has knowledge beyond the limits of human rationality, something that is fiery and fiercely amoral, and lies veiled in darkness, refers to our unconscious impulse...it belongs to that covert part of the human nature psychoanalysts call the id. (p. 23)

Pey, existing at the edge of rationality breaking laws and taboos, thus belongs to the dark part of the consciousness - the id. The kanni pey's desire for women or kaniam pey's desire for jewelry are repressed desires of the people of the Karisial Kädu expressing itself in dark veiled forms.

It is interesting to note that pey, the dark part of the consciousness of the Karisial is associated with singing and dancing in these stories. The only time the stories refer to dance and music is in association with the pey. However, it is not an evolved or a sophisticated performance. 
It cannot be bracketed as an autonomous category called art nor does it concern itself with entertainment. At the heart of the singing and dancing is an excess; it is to be noted that the pey begins its singing and dancing as a response to an overwhelming emotion. The position of the pey in the Karisial cosmos is also of significance: existing at the edge of the society, pey is the repressed excess of the consciousness. The singing and dancing of the pey, then, is a response to and a manifestation of an excess. The paper sees the aesthetics associated with the singing and dancing of the pey as aesthetics of excess and explores it through Nietzsche's idea of the Dionysian and Dionysian drunkenness.

The Dionysian, as an aesthetic category conceptualized by Nietzsche from the divine world of the Greek god Dionysius, embodies excess. Soyinka (1990) calls Dionysius a terrestrial deity and says that terrestrial deities bear excess, hubris, or other human weaknesses. He says

The seed of anti-terrestrialism sowed by Buddhism and Judeo-Christianity had to end with such excesses as the transference of the underworld to a new locale up in the sky, a purgatorial suburb under the direct supervision of the sky deities. (p. 4)

The Pey that deviates from the transcendental deities of scriptural Hinduism has more in common with Soyinka's category of terrestrial deities. Hence it will be fruitful to look at the singing and dancing of the pey through the lens of the Dionysian, the aesthetic category formulated by Nietzsche.

In opposition to the Apollonian, Nietzsche posits the Dionysian as an aesthetic category, a glimpse of which is possible he says (taking recourse to Schopenhauer) if we add "blissful ecstasy" to the dread that "grips man when he suddenly loses his way amidst the cognitive forms of appearance"; i.e. with the "fragmentation of the principium individuationis". As much as Schopenhauer's “dread", Nietzsche's "blissful ecstasy" too rises from "man's innermost core, indeed from nature", and he explains it further through the analogy of intoxication (Nietzsche, 1872/ 1993, p. 49). Marked by disorder and the unformed, the Dionysian is in opposition to the Apollonian, "the gestalt of good forms", marked by identity and order (Weiss, 1989, p. 6). While the Apollonian embodies the Delphic dicta of "know thyself" and "everything in moderation", the Dionysian says that contradiction is at the heart of things in nature. Taking shape from pain, the dionysian shows that "excess revealed itself as truth" (p. 10). The Dionysian hence sees the principle of individuation as repressive and limiting. Morality and identity determined by moderation are degradation or decay. Debunking morality as a denial of life, the Dionysian for Nietzsche is life-affirming.

The Dionysian helps man be free from the slavery of the principle of individuation. It helps him connect with the primordial. With the shattering of individuation, man rises above his self, to connect with the collective whole, of which he is a part. He connects with his neighbor and above all himself (Nietzsche, 1872/1993). By shattering the principle of individuation, overcoming his fragmented individuality, man becomes whole through the Dionysian frenzy. Weiss (1989) says that the Dionysian frenzy is the expenditure of the libidinal energy here and its purpose is to attain the whole man. This expenditure of the libidinal energy is marked by excess.

The Dionysian frenzy, unrelenting before any kind of restraint, attains the fullness in man. This Dionysian intoxication is converted into an Apollonian dream or vision in drama. Weiss (1989) says this transformation into a "public, communal vision or sign" of "a private excitation and passion" is drama (p. 4). The purpose of drama, then, is to convert libidinal energy into a sign. However, the frenzied dance and loud music of the pey in a state of Dionysian intoxication are yet to transform into a public communal vision or sign. Thus the singing and the dancing of the pey are yet to evolve into drama. 
Not transformed into an Apollonian vision, the singing and dancing of the pey are characterized by excess. Nietzsche sees frenzy as something that enables excitability leading to increased strength and fullness. Art is possible from the frenzy; without this, he says there is no art (Weiss, 1989, p. 5). Pey that exists at the edge of the society is the only being that is capable of being in a state of frenzy or embody an aesthetic of excess from which art could emerge. As the shadow of the Karisial consciousness, pey represents a possibility of attaining the whole man, otherwise fragmented in the mundane social order of the Karisial Kādu, by moving beyond the principle of individuation through the frenzy, an excess. The singing and dancing of the pey are not (yet) transformed into an Apollonian vision, a sign, and hence can be seen as proto-drama.

Not transformed into a communal sign, the singing and dancing, termed as proto - drama is not necessarily aesthetically pleasing to the people of the Karisial Kädu. Described variously as screams, eerie melody, frenzy, and wild, it does not always fulfill the accepted standards of 'beauty' to qualify as enjoyable or for that matter acceptable to the people in these stories. Nowhere in the stories is there a mention of people being appreciative of the singing and the dancing of the pey, not to mention that it is considered to be intolerable by Anjādhān in story number 32 as described above. It is to be noted that, unable to tolerate the pey's screams, Anjādhān pokes the pey with the trident. The singing is not only discordant but also unbearable here. The singing and dancing, hence, do not concern themselves with 'beauty'.

There are two genres of singing and dancing associated with the pey - one when it sings through other people by possessing them and the other when it dances and sings on its own. The first genre of singing and dancing by possession - seen in story number 55 where kaniam pey possesses the exorcist and starts to sing through him - is a possession. Brought about by pey, a dual spirit that is not categorized as pure, the possession is a malign spirit possession (Kapadia, 1996). The second genre of singing and dancing where the pey sings and dances on its own is seen in four instances, twice in story number 32 where the pey begins to sing and dance on seeing the Aiyyannar eat the bananas and when it begins to wail when Anjādhān pokes it with a trident, in story number 37 when it dances and sings with Gomathi's diamond necklace and in story number 55, the amorous song and frenzy that the pey is about to enter into when it gets the scent of the new bride. The two genres of singing and dancing vary in their purpose as much in their form.

The first genre of singing and dancing - the malign spirit possession - is communication. The singing communicates the cause of Puvāyi's distress and prescribes the cure for it. Though the story doesn't give many details about the nature of the singing, it can be concluded that the singing is comprehensible. There is thus some sort of moderation associated with it unlike the song in story number 32 where the singing is described as screams. The trance that the exorcist enters into after being possessed by the pey is controlled allowing the singing to be deciphered.

The singing by the possessed exorcist also gives enough information to identify the possessing spirit. The description in the singing about the arousal by the scent of the new bride is enough indication for the people of Karisial to identify the kaniam pey. The possession, the music associated with it especially, is identificatory here. The change in identity is marked by stylized gestures that are recognizable and are hence a collective representation. With the music, the stylized gestures help in identifying the possessing god. The music here is thus identificatory (Rouget, 1980/1985). Though the stories don't give enough details about any stylization associated with the singing of the possessed exorcist, the singing is sufficient for the people of Karisial to identify kaniam pey as the one possessing the exorcist. The first genre of singing while being communication is also identificatory. 
In the whole episode of the pey possessing the exorcist - the singing giving solutions and the enactment of those instructions by an obedient people - it assumes the role of a healer similar to that of a shaman, or a traditional healer. Healing for the traditional healer unlike his modern counterpart is not merely about the body and the mind. More importantly, it is a process that helps one reintegrate into society. The illness alienates one from the meaningful whole of the collective tradition (Kakar, 1982). Puvāyi's distress is not merely a personal condition she is in; it is linked to the cosmos of the Karisial and its collective myth. Puvāyi's delirium, a disturbance brought about by the pey, connects with her struggle to fit into the structure of the family and her role of a wife in it, as also with the integration of the new bride - an embodiment of sexuality and fertility, as a new element into the socio-cosmic order of the Karisial. The pey, which brings about this disturbance, is the excess, the madness that the consciousness of the Karisial Kädu rejects and overcomes - in the healing of Puvāyi - to maintain its socio-cosmic order.

Puvāyi's distress, caused by pey - the turbulent dark passion in the underside of the consciousness of the Karisial Kädu - is communicated through a communal sign in the figurative possessed singing. Thus the excess or madness is represented through an acceptable and comprehensible semiotic system. Through such communication, the wife returns to the structure of the family and a woman's role in it (Nabokov, 1997). Putting the participants in touch with the dark, the unformed, the turbulent part of consciousness, the communal sign thus brings about a cathartic purification. Weiss (1989) sees catharsis as the consequent purification of the Dionysian madness. The figurative possessed singing in itself is the cure here. The singing, in this instance, then, aids in reinstating the harmony of society.

The stories give more details about the second genre of singing and dancing where the pey is the performer, unlike in the first genre where it sings through other people by possessing them. The singing and dancing of the pey, described as loud and frenzied, is always a direct response to an overwhelming emotion. It is evident in story number 32, first when a stupefied pey begins to sing and dance seeing the idol of Aiyyannar eat the bananas it offers; and then again when Anjādhān pokes the pey with the trident, the terrified pey begins to sing. In story number 55, it sings an amorous song and is about to get into frenzy when aroused by the scent of the new bride, and in story number 37, the kani pey steals Gomathi's diamond necklace and sings and dances with it. The singing and dancing are born out of the pey's amazement, fear, desire, and celebration in these instances. These emotions emerging from awe, fear, or shock break composure to embody excess and this gets manifested in the singing and dancing of the pey. The second genre of singing and dancing is thus a manifestation of an excess.

A manifestation of excess, the second genre of singing and dancing, doesn't lend itself to any kind of control or moderation. Described as wild, untamed, and uncontrolled, it is in a state of frenzy or complete trance. This singing and dancing, unlike in the partial and controlled trance associated with the first genre of singing and dancing, is not representational. There are no stylized gestures signifying a possession by or a representation of an external entity or activity. Hence, it doesn't symbolically represent an entity as in the singing of the possessed exorcist. Being neither representational nor identificatory, the singing and dancing here is void of any figurative function.

The frenzy or the complete trance does not maintain a pattern or a shape and hence varies from ritualistic singing and dancing in pre-modern societies. Schechner (2007), talks about performances in pre-modern societies, where art is yet to evolve into an autonomous category, as patterns of doing rather than modes of thinking. Dance associated with shaman-dancers of premodern temple-theatres maintained a persistent shape which was kept from one event to another. Adherence to order and control enables the singing and dancing to maintain a pattern or a shape. 
The frenzy that breaks all forms of order and control fails to maintain patterns or shapes. It hence moves towards an aesthetic of the unformed and disfigured. Embodying the Dionysian intoxication, it is a pure expression of libido. The singing and dancing here is a primal mode of expression.

The frenzied dancing and singing, a pure expression of libido in the second instance, brings about a fusion of the subject with the primal being. In such a fusion the music itself is the very copy of the primal unity and is its very sign (Weiss, 1989). While the unformed, disintegrated, nonfigured singing and dancing in the second genre don't transform into an Apollonian vision or sign, the whole body becomes a sign here. Drunken in this frenzy, the body itself becomes the pure expression of the libido. It is not a sign born out of an act of controlled, restrained representation pointing to an excess outside of itself. The difference between the first and second genres of singing and dancing, then, is that of representation and metamorphosis (Weiss, 1989).

The social function associated with the first genre of representational singing and dancing is apparent. Assuming the role of a healer, the pey, through its singing, cures Puvāyi of her distress and integrates her into the socio-cosmic order of the Karisial Kädu. The second genre of singing and dancing, however, is not associated with any apparent social function. The pey doesn't assume roles of any sort nor is it part of a ritual. There is no catharsis associated with the second category of singing and dancing as with the first genre of figurative possession. The unformed, disintegrated singing and dancing of the second genre, devoid of Apollonian forms, is not capable of a cathartic purification as in the first genre. It, however, shatters individuation itself. Nietzsche (1872/ 1993) says the shattering of individuation allows man to rise above the ego to connect with the primordial unity. The frenzy thus helps in realizing the whole man. The principle of individuation in itself is the malaise here and the cure is the realization of the whole man.

The second genre of singing and dancing even without catharsis is potentially therapeutic. The purification here is from the ego to embrace the whole self. Weiss (1989) calls both the figurative and dis-figurative possession therapeutic as both help in realizing the whole man by shattering the principle of individuation. If in one it's through representation, in the other it's through a metamorphosis; by transforming into a sign and becoming a sign. However, human participation is limited in the singing and dancing in the second genre. The only instance of human participation in the second genre is when Gomathi strips naked and joins the pey in their dance. Anjādhān, on the other hand, finds it unbearable and chases the pey away as he can't bear its screams. Nevertheless, the second genre of singing and dancing, by shattering the restrictive principle of individuation, also potentially aids in maintaining the socio-cosmic order of the Karisial Kādu.

\section{Conclusion}

The singing and dancing of the pey, a manifestation of the rejected excess of the socio-cosmic order of the Karisial Kādu, is marked by an aesthetic of excess. Anathema to ideas of beauty and harmony, the aesthetic of excess disturbs composure. It is hence considered discordant and sometimes unbearable in these stories. The discordance of the singing and dancing of the pey, however, aids in maintaining the socio-cosmic order of the Karisial Kädu. The excess, the madness it entails, and the consequent understanding and encounter with it, as seen in the first and second genres of singing and dancing, is a way to maintain the harmony of the Karisial Kädu.

Art when it becomes an autonomous category, concerned with beauty and harmony, brings in moderation by weeding out the excess. This is best exemplified in Abhinavagupta's preference of śánta rasa as the foremost rasa and transcendence as the desired function of art. Disturbance of 
composure, however, is what brings about harmony in the singing and dancing of pey. The excess, which classical aesthetics deems undesirable and weeds out is not only embodied in the singing and dancing of pey but is also considered sacred and part of the process of maintaining the sociocosmic order in Karisial Kādu.

The aesthetics of excess embodied in the singing and dancing of the pey emerge from the sacred in the Karisial Kädu. Constituted by local deities, libidinal excess marks divinity here. The singing and dancing, linked to this libidinal excess are an expression of the Karisial Kādu populated by local deities in these stories. The aesthetics of excess associated with it is the demotic that deviates from the classical idea of aesthetics. Even when excess gets undermined in Nâtyaśāstra, the codified treatise on poetics, the connection between the libidinal excess and drama cannot be dismissed.

\section{References}

Bayly, S. (1992). Saints, goddesses, and kings: Muslims and Christians in South Indian society 1700-19oo. Cambridge University Press. (Original work published 1989)

Fuller, C. J. (2004). The camphor flame: Popular Hinduism and society in India (Rev. \& expanded ed.). Princeton University Press. https://doi.org/10.1515/9780691186412

Gerow, E., \& Aklujkar, A. (1972). On śānta rasa in Sanskrit poetics. Journal of the American Oriental Society, 92(1), 80-87. https://doi: 10.2307/599651

Kakar, S. (1982). Shamans, mystics, and doctors: A psychological inquiry into India and its healing tradition. Oxford University Press.

Kapadia, K. (1996). Dancing the goddess: Possession and class in Tamil South India. Modern Asian Studies, 30(2), 423 -445. https://doi.org/ 10.1017/Soo26749Xooo16528

Masilamani-Meyer, E. (2004). Guardians of Tamilnadu: Folk deities, folk religion, Hindu themes. Verlag der Franckeschen Stiftungen zu Halle.

Mines, D. P. (1997). Making the past past: Objects and the spatialization of time in Tamilnadu. Anthropological Quarterly, 7o(4), 173-186. http://doi:10.2307/3317224

Muni, B., \& Rangacharya, A. (2018). The Nātyaśāstra: English translation with critical notes. Munshiram Manoharlal Publishers. (Original work published 1984)

Nabokov, I. (1997). Expel the lover, recover the wife: Symbolic analysis of a South Indian exorcism. The Journal of the Royal Anthropological Institute, 3(2), 297-316. http://doi:10.2307/3035021

Nietzsche, F. (1993). Birth of tragedy: Out of the spirit of music. (S. Whiteside, Trans. \& M. Tanner, Ed.). Penguin Books. (Original work published 1872)

Rajanarayanan, K. (Ed.). (2006). Națupura katai kalañiyam [repository of folktales] (3 $3^{\text {rd }} \mathrm{ed}$.). Akaram.

Rajanarayanan, K. (Ed.). (2008). Where are you going, You monkeys? (P. K. Chakravarthy, Trans.). Blaft Publications. (Original work published 2006)

Ramanujan, A.K. (1986). Two realms of Kannada folklore. In S.H. Blackburn \& A.K. Ramanujan (Eds.), Another Harmony (pp.41-76). University of California Press.

Rao.P.S.R.A. (1967). A monograph on Bharata's naaTya Saastra. Naatya Maalaa Publishers.

Rouget, G. (1985). Music and trance: Theory of the relations between music and possession. (B. Biebuyck \& G. Rouget, Trans.). The University of Chicago Press. (Original work published 1980) 
Schechner, R. (2001). Rasaesthetics. The Drama Review: TDR, 45(3), 27-50. https://doi.org/10.1162/10542040152587105

Schechner, R. (2007). Drama, script, theatre, and performance. The Drama Review: TDR, 17 (3), 5-36. https://doi.org/10.2307/1144841

Schwartz, S. L. (2008). Rasa: Performing the divine in India. Motilal Banarsidass Publishers.

Soyinka, W. (1990). Myth, literature and the African world (Canto ed.). Cambridge University Press.

Varadpande, M. L. (1981). Ancient Indian and Indo-Greek theatre. Abhinav Publications.

Venkatachalapathy, A.R. (2018). Cho. Dharman: Peacock on black cotton soil. In A.R.Venkatachalapathy (Ed.), Tamil Characters: Personalities, Politics, Culture (pp.205-220). Pan Macmillan.

Weiss, A. S. (1989). The aesthetics of the excess. State University of New York Press.

Swathi Sudhakaran has a BA in English from EFL University and an MA in English Language and Literature from University of Hyderabad. She is currently a PH.D candidate at the Humanities and Social Sciences Department, IIT Madras. Her broad areas of research interest lie in the field of literary and performance studies, especially on questions concerning aesthetics.

Milind Brahme has a PhD in German Literature from the Centre of German Studies, JNU. He teaches at the Department of Humanities and Social Sciences at IIT Madras. Areas of teaching and research interest are German language and literature and Literary Theory. He also works on questions of pedagogy and education. 